\title{
Electrophoretic protein profiles of rat gonads during differentiation
}

\author{
A. P. Banerji, A. K. Dubey, S. Sarkar and P. N. Shah \\ Division of Endocrinology, Cancer Research Institute, Parel, Bombay 400 012, India
}

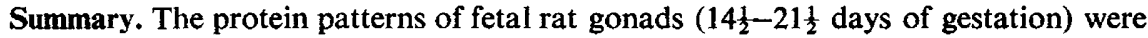
examined by SDS gel electrophoresis. Male gonads contained more protein components at all stages.
\end{abstract}

Cellular differentiation is associated with changes in the protein composition, and observations of the protein patterns during growth and development of an organ represent an attempt to study cellular differentiation. The protein patterns of late fetal and postnatal tissues of the rat (Serman \& Skreb, 1970) and of well differentiated adult organs of a number of mammalian species (Comings \& Tack, 1972) have been reported, but information on differentiating rat gonads is not available. This communication reports the changes in the protein profiles of the gonads of rats between $14 \frac{1}{2}$ and $21 \frac{1}{2}$ days of gestation.

Gonads were removed from Wistar rat embryos of both sexes at known gestational ages (20-25 gonads/group), pooled according to sex and age, and stored at $-20^{\circ} \mathrm{C}$ for not more than $48 \mathrm{~h}$. The sodium dodecyl sulphate (SDS) gel electrophoretic method of Maizel (1971) was followed with $7.5 \%$ acrylamide gels and tris-glycine buffer, $\mathrm{pH} 8.5$, containing $0.1 \%$ SDS. Protein was extracted from the pooled tissues by homogenization with chilled $0 \cdot 1 \mathrm{M}$-saline-EDTA buffer, $\mathrm{pH} 8 \cdot 0$, for $7 \mathrm{~min}$ and the extracts were centrifuged at $650 \mathrm{~g}$ for $20 \mathrm{~min}$ to obtain clear supernatants. All operations were carried out at $2-4^{\circ} \mathrm{C}$. The extracts, representing total gonadal proteins from the entire gonad, were brought to $1 \% \mathrm{SDS}$ concentration and solubilized by heating at $100^{\circ} \mathrm{C}$ for $3 \mathrm{~min}$ in the presence of mercaptoethanol. SDS-treated protein samples equivalent to $100 \mu \mathrm{g}$ protein were loaded on to the gels. Sephadex G-200 was used as a stacking gel and electrophoresis was carried out by applying a current of $3 \mathrm{~mA} /$ tube with bromophenol blue as the marker dye. Standard marker proteins of known molecular weights, e.g. lactic acid dehydrogenase $(37,000)$, bovine serum albumin monomer $(68,000)$, lactoperoxidase $(78,000)$ and bovine serum albumin dimer $(136,000)$, were similarly treated and electrophoresed under identical conditions to assess the molecular weights of the gonadal proteins. Gels were stained with $0.025 \%$ Coomassie brilliant blue and scanned at $545 \mathrm{~nm}$ in a Densicord electrophoresis densitometer (Model 552). Protein content was determined by the method of Lowry, Rosebrough, Farr \& Randall (1951).

Comparison of the electrophoresis patterns for $14 \frac{1}{2}$-day testis and $14 \frac{1}{2}$-day ovary showed that there were more protein components in the testis than in the ovary (Pl. 1, Fig. 1). The extra protein components were seen at both ends of the gel. This difference in the components in the two molecular weight regions between the gonads of each sex was observed throughout the gestation period surveyed and was reproducible. The observation is associated with the morphological differentiation of Sertoli cells which first appear in the testis at $14 \frac{1}{2}$ days, a time when the ovary is morphologically undifferentiated (Mittwoch, Delhanty \& Beck, 1969; Jost, Vigier, Prepin \& Perchellet, 1973). It also agrees with the report of Mittwoch et al. (1969) who found a higher growth rate of testis than ovary during fetal life. On Day $15 \frac{1}{2}$, when sex cords are being formed in the testis, the difference in the protein patterns between the testis and the ovary was maintained and extended by the appearance of new proteins in the testis in the higher molecular weight region (Pl. 1, Fig. 2). At 16 $\frac{1}{2}$ days, when the testicular sex cords are becoming more compact and encircling the germ cells and Sertoli cells, the protein pattern was the same as on Day $15 \frac{1}{2}$. On Day $17 \frac{1}{2}$, the tunica albuginea is being formed in the testis and there were more protein components in the molecular weight range of 37,000-78,000 and some in the high molecular weight region (PI. 1, Fig. 3). In the ovary, although there were more 
proteins in the region of 78,000 and 136,000 on Day $17 \frac{1}{2}$ than on Days $14 \frac{1}{2}$ and $15 \frac{1}{2}$, a diminution of proteins in the molecular weight region of 37,000 was observed. This difference between the gonads

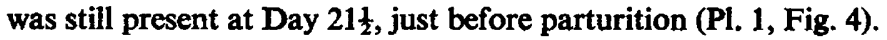

It is clear that although the gonads of fetal rats of both sexes have changing protein profiles with age, there are always more protein components in the testis than in the ovary. Mittwoch et al. (1969) suggested that the fetal gonadal rudiment has to reach a critical size to develop into a testis, the increase in cell proliferation being mediated by the Y chromosome (Jost et al., 1973). Our observations show that the attainment of the critical size, and thence the superior growth rate, of the testis can be associated with its greater number of protein components.

\section{References}

Cominas, D.E. \& TACK, L.C. (1972) Similarities in the cytoplasmic proteins of different organs and species examined by SDS gel electrophoresis. Expl Cell Res. 75, 73-78.

Jost, A., Vigier, B., Prepin, J. \& Perchellet, J.P. (1973) Studies on sex differentiation in mammals. Recent Prog. Horm. Res. 29, 1-41.

LOWRY, O.H., Rosebrough, N.J., Farr, A.L. \& Randal., R.J. (1951) Protein measurement with the Folin phenol reagent. J. biol. Chem. 193, 265-275.
MatzeL, J.V. (1971) Polyacrylamide gel electrophoresis of viral proteins. In Methods in Virology, Vol. 5, pp. 179-244. Eds K. Maramorosch \& H. Koprowski. Academic Press, New York.

MitTwoch, U., Delhanty, J.D.A. \& Beck, F. (1969) Growth of differentiating testes and ovaries. Nature, Lond. 224, 1323-1325.

Serman, D. \& Skreb, N. (1970) Protein patterns during final differentiation of some rat organs. Wilhelm Roux' Arch. EntwMech. Org. 165, 277-284.

Received 17 June 1977 

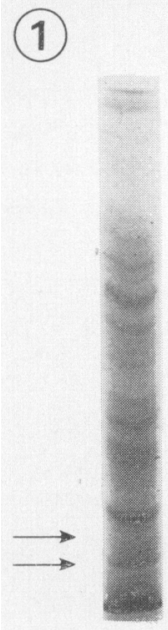

(a)

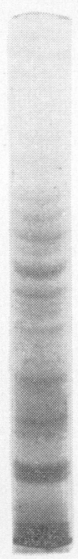

(b)

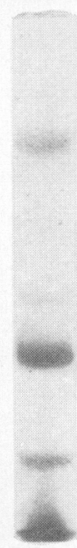

(c) $\longleftarrow 78,000$

$\longleftarrow 68,000$

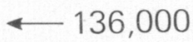

$$
\leftarrow 37,000
$$

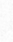

(3)

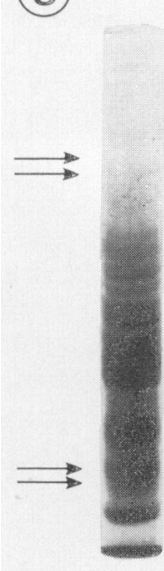

(a)

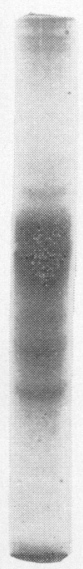

(b)

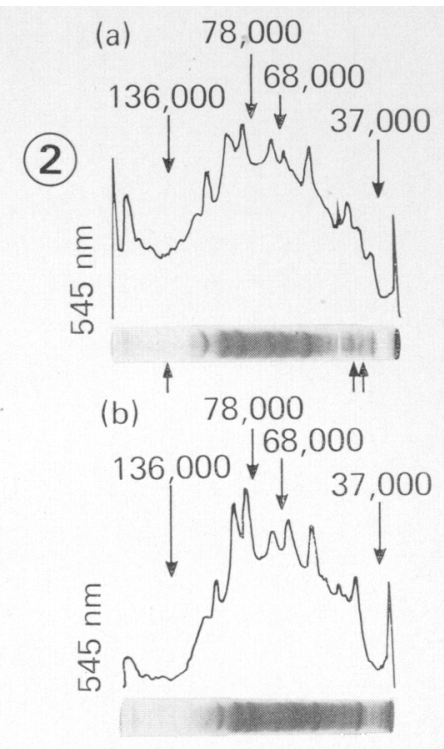

(4)

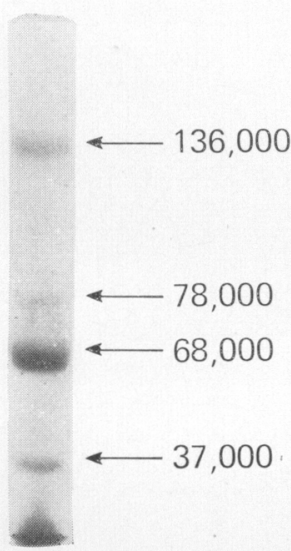

(c)

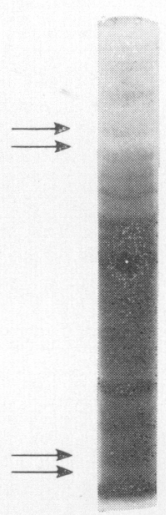

(a)

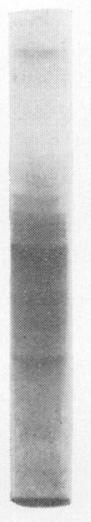

(b)

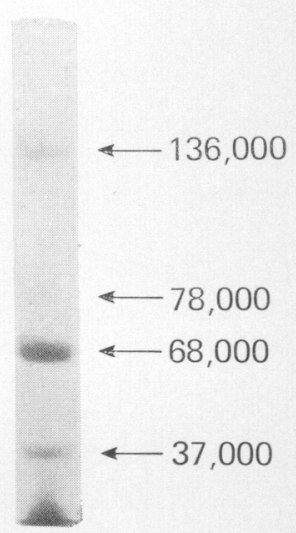

(c)

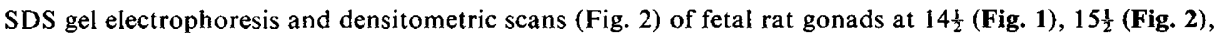
$17 \frac{1}{2}$ (Fig. 3) and $21 \frac{1}{2}$ (Fig. 4) days of gestation. In each figure, (a) $=$ testis, $(b)=$ ovary, and (c) $=$ the gel with the marker proteins (see text). Arrows on the testis and ovary gels indicate regions where there are differences in the protein components of the gonads. 